\title{
酉 $\mathrm{K} \alpha \gamma \mathrm{Q}^{1}$ \\ Kaygı Uludağ Üniversitesi Fen-Edebiyat Fakültesi Felsefe Dergisi \\ Uludağ University Faculty of Arts and Sciences Journal of Philosophy \\ Sayı 23 / Issue 23 | Güz 2014 / Fall 2014 \\ ISSN: 1303-4251
}

Araştırma Makalesi

Research Article

Melis AKTAŞ

PhD. Candidate | Doktora Öğrencisi, University of Strasbourg, Faculty of Philosophy, Strasbourg-France melisaktash@gmail.com

\section{The Question of Man-Citizen Cooperation in the Declaration of Rights of 1789 from a Marxian Perspective}

\begin{abstract}
The Declaration of Rights of 1789 has been always regarded as a gain of "rights" in the domains of freedom, equality and right of property in the history of man. While we find within it "Man" and "Citizen" as the keywords we usually ignore what these are actually standing for. In fact this division of "Man" and "Citizen" is nothing but an affirmation of capitalism offering people to lead two separate lives in two distinct realms. This in turn gives us the possibility to come across the abstract "Man" covering up its being the bourgeois himself in reality along with the legal term "Citizen" infused with morality, introduced as if in a justification of his demand for the rights. And just there we find Marx who in his way puts an end to the dissimulation in question. So this work aims, in the line of Marx, an uncovering of the identities of the "Man" and "Citizen" in the declaration.
\end{abstract}

\section{Keywords}

Social contract, Natural man, Citizen, Freedom, Equality, Property, Bourgeoisie, Capitalism. 
The Question of Man-Citizen Cooperation in the Declaration of Rights ...

The year 1789 stands as a symbolic point in the history of man designating the rise of capitalism along with the Declaration of Rights, which preceded France's new constitution. However, for Marx, this declaration appears to have been prepared especially to found the "exclusive realm of Freedom, Equality, Property and Bentham within whose boundaries the sale and purchase of labour-power goes on" (Marx, 1977: 280). So, on this point we should probably ask: on the way up to communism set up by Marx, what does a declaration like this signify? There, along with their own context, the key notions like liberty, equality, property, always remain to be interrogated as to whom and to what they serve? On the other hand, "who is this "man" in the declaration?" has always been a popular question on the part of the academics; that cannot be denied. In fact, the ambiguity of this Man-Citizen weakens the impact of these pompous key notions which have already had contestable characters. So taking all this into account, here, I will try to analyse the Declaration of Rights of August 26, 1789 asking on the whole whether the "man" and the "citizen" correspond to the same man or whether they should always remain as separate entities.

First of all, I'd like to roughly set as a background the social contract theories of Thomas Hobbes and John Locke. As it is well known, these theories opposed the view that society was an organism having parts allocated to all the steps constituting the social ladder, i.e. from serfs to the king; so that it was a natural order that helped society to operate as a single entity. With the dawning of capitalism however thinking of society in substantial terms which was especially effective in ancient and feudal times began to give way to "the analogy with an aggregate. Just as a pile of sand is merely an aggregate of bits of sand rather than a whole entity with parts and tendencies, so a society is merely an aggregate of individuals having no intrinsic connection with one another but relating in an external way, through contract" (Carver, 1991:310). And there comes Hobbes' theory of social contract. According to this theory in their natural environment human beings are only in the pursuit of their own interests and power; and this, in turn creates conflicts with one another since the interests of each collides with those of others and then what counts becomes the war of all against all. As a result, people should agree on some set of political institutions in order to overcome the conflicts within the anarchic and asocial state and to secure their lives thereby. Essentially Hobbes was for a dictatorship (in the case of England that of Cromwell's) in which people surrender their rights to this one man who is to protect these rights and establish the society in an order. However John Locke, in contrast with the absolutist tendencies of Hobbes and under the influence of the Glorious Revolution of 1688 in England, published -in an attempt to justify the recent events- his Two Treatises of Government in which he "maintained that humans had originally lived in a state of nature in which absolute freedom and equality prevailed, and in which there was no government of any kind. The only law was the law of the nature, by which individuals enforced for themselves their natural rights to life, liberty and property" (Coffin, 2002: $610)$. However they began to realize that when everyone was after his or her own rights, "confusion and insecurity were unavoidable results" (ibid). So people decided to constitute among themselves a civil society "based on absolute equality, and then set up a government to act as an impartial arbiter of disputes for the society they already created"(ibid). On the other hand, these people conferred to the government only the 
executive power based on the law of nature. The government they created was not absolute and "the state was nothing but the joint power of all members of society. (...) All governmental authority was thus contractual and conditional” (ibid: 611). So in the case that a government acted in tyrannical ways, then the society had the rights to dissolve it and constitute another.

Whatever the differences between Hobbes and Locke are (whether it is their description of the natural state of humans, or their governmental choices) what they held common was too remarkable to be ignored: the placing of the right to liberty of the individual as the natural right. From this point on, we are led to consider its direct relation with the right to property itself, since in the simplest terms, one needs his or her own resources to stay in life. So when Hobbes says that man is self-interested, he points out the fact that in this way, man has some system of private property "such that each is able to own the products of his or her own efforts" in the state of nature and even when people yield their rights to the ruler in the name of the social order, they take for granted that their rights of property is to be protected by the sovereign. Locke takes property to be a natural attribute of man as well and forms a link between the institution of government and the preservation of property. The man described by Hobbes as competitive and as self-aggrandizing and by Locke as free and (allegedly) equal with others surely reminds us of the division of people in capitalist societies into citizens and members of civil society. Critics of contractarianism including Karl Marx draw our attention to the similarity of man in the state of nature to the one in civil society participating in "capitalist economic transactions" (Carver: 163). Regarding this point, in On the Jewish Question Marx says: "Man, as he is a member of civil society is taken to be the real man, man as distinct from the citizen, since he is man in his sensuous, individual and immediate existence whereas political man is simply abstract, artificial man” (Marx, 2002: 63). So in short, classical social contract theories can serve as a mirror for us reflecting the "atomized assemblage" (Carver: 310) of egoistic individuals under the disguise of natural man constituting the capitalist society.

If we come back to the Declaration of the Rights of Man and Citizen, we can easily notice, in the first place, that the division of "Man" and "Citizen" is highly remarkable in its affirmation of capitalism offering people to lead two separate lives in two distinct realms: on the one hand there is the "Man" within the private realm, in other words in civil society finding himself in the competitive pursuit of personal gain; on the other hand there is the "Citizen" within the public realm which is the "state characterized by shared laws and common interests" (ibid: 163). So in a way the "Citizen" appears to be the "Man" himself who, in order to prevent the inconveniences caused by the clash of interests in a natural state enters a social contract in return of which he expects his certain "natural” rights to be guaranteed. The important point here is that the capitalist system acknowledges both the natural man and the man bound by the contract, i.e. the citizen, since what is seen in the social contracts as the surrendering of his rights for the sake of an orderly society is transformed to the fact that capitalism both takes the so-called rights in its hands, subjects them to certain limits after the laws and regulations and also gives a chance to the "Man" along with his rights, or to put it more properly to the "rights" which, reduced to abstractions and made a subject, enables "Man" to be defined in accordance with itself (as its predicate) and allows him to enjoy 
his "natural" rights in the private realm. In other words capitalism aims to make use of human nature within which "war of all against all" is redefined as competition related to his "natural" faculty of exchange associated with man's "most essential right" i.e. private property.

On the other hand, returning to the title of the declaration, there, we note that the word "Citizen" applies to everyone bound by the laws to carry out certain duties and thereby can be held to include a kind of morality which is for Marx full of religious implications. The word "Man" is much more problematic in that it is a mere abstraction preventing one to give an answer to the question "Who is this 'Man'?" An abstraction of a man is taken to be the real man and Marx dwells on this erroneous point in an attempt to refute it; after all he is the one who is after the real man, namely as one of his central terms which he borrowed from Feuerbach, the "species being" -not as an abstraction but "as our distinctive capacity for producing 'free from physical need", (Ameriks, 2000: 269). In short, the main point the criticisms have centered on, is this declaration of "inalienable human rights -reckoning- with an 'abstract' human being who seemed to exist nowhere” (Arendt, 1962: 291).

It might be possible for us, though, to be led to the identity of this "Man" in the Declaration of Rights of 1789 if we follow the course from Marx's definition of a capitalist society, since as I have already mentioned this declaration acts on its own as an affirmation of the capitalist system. "A society is capitalist, in Marx's way of thinking, if the production of the material goods is dominated by the use of wage labour, that is, the use of labour power sold, to make a living, by people controlling no significant means of production and bought by other people who do have significant control over means of production and mostly gain their income from profits on the sale of the results of combining bought labour with those productive means" (Carver: 55). So it is quite clear that Marx presupposes two groups in society and according to this definition the first group is the proletariat and the second one is the bourgeoisie. Subsequently this division of classes necessitates one to be the dominant one controlling resources "such as labour power, people, land, raw materials, technology, skills and knowledge, and goods whose exchange yields productive resources” (ibid: 98). And the legal and political superstructure and definite forms of social consciousness are determined by the class dominating over the economic structure; in this case the bourgeoisie is the dominant class, so the ruling class, politically. For a compact historical background of the bourgeoisie we can resort to the following lines from Communist Manifesto:

"Each step in the development of the bourgeoisie was accompanied by a corresponding political advance of that class. An oppressed class under the sway of the feudal nobility, an armed and self-governing association in the mediaeval commune, here independent urban republic (as in Italy and Germany), there taxable 'third estate' of the monarchy (as in France), afterwards in the period of manufacture proper, serving either the semi-feudal or the absolute monarchy as a counterpoise against the nobility, and, in fact, corner-stone of great monarchies in general, the bourgeoisie has at last, since the establishment of Modern Industry and of the world-market, conquered for itself, in the modern representative state, exclusive political sway. The executive of the 
modern State is but a committee for managing the common affairs of the whole bourgeoisie” (Marx \& Engels, 1992: 15-16).

The third estate, i.e. the commoners as mentioned above, reconstituted under the name of the National Assembly of France was responsible for the preparation of a new constitution in 1789 and it seemed more suitable to preface it with a declaration of the rights which were "inalienable, irreducible to and undeducible from other rights or laws” (Arendt: 291) and upon which this new constitution was to be based. On 26 August 1789, the Declaration of the Rights of Man and the Citizen was adopted by the National Assembly. "If we sum up all these, the constitution was prepared by the bourgeoisie and according to Marx's information above, it is obvious that the laws and their executions thereby are just a "managing -of- the common affairs of the whole bourgeoisie" (Marx \& Engels, 1992: 16). So to whom do the rights it talks about belong? Again, in On Jewish Question, Marx puts forward an answer for this: "The first point we should note is that the so-called 'rights of man' as distinct from the rights of the citizen are quite simply the rights of the member of the civil society, i.e. of egoistic man, of man separated from other men and from the community” (Marx, 2002: 59). "Egoistic Man", i.e. the famous natural man which has been said to be within the private realm in the capitalist society, is now completely identified as the member of the bourgeoisie. Distinguished from the citizen, in the Declaration of Rights he is called "Man" and his rights are called "rights of man".

The first article of the Declaration of the Rights of Man and the Citizen reads: "Men are born and remain free and equal in rights. Social distinctions may be founded only upon the general good". This reminds us of Locke's theory that in their natural state people were leading a life as free and equal individuals; but even in this utopic depiction of a state, they saw that their freedom in the pursuit of their natural rights began to collide with the freedom of others and, as I have already mentioned, they set up a civil society as a solution to this confusion. The expression of "social distinctions" in this article seems to be in a contradiction with the first sentence. When talking about equality as a natural right, there come the "distinctions". The ones who wrote down this article must have realized this contradiction as well that they justified the "social distinctions" as their being founded upon the general good. Furthermore, it is obvious that the speaker here is a member of the bourgeoisie representing "its interest as the common interest of all the members of society” (Marx \& Engels, 2005: 39). So in a way, even when it is said that men are naturally free and equal to each other, because of the conflicts caused by these seemingly positive traits, for the sake of common good it is better to have some inequality among men, which is to serve as a frame determining the limits of the freedom.

Agamben, in his work entitled Homo Sacer: Sovereign Power and Bare Life (1995), in a reference to Hannah Arendt, notes that with this article it is the simple fact of birth which carries the right; in a way the bare life is the source of the right; “(....) however, the very natural life that inaugurating the biopolitics of modernity, is placed at the foundation of the order vanishes into the figure of the citizen, in whom the rights are "preserved"” (Agamben, 1998: 75). So this point is highly crucial in dealing with this apparently abstract "Man" in the declaration, since "Man" appears only within the limits of being a citizen; and this inevitably reminds us of the ancient Greek city-state (polis) 
in which one could find the limits of the human; in other words what is man was there already a subject of right, so he was directly a political agent. The ancient Greek society was horizontal in the sense of being egalitarian; however one who didn't have access to this plan found himself outside the city-state, outside the society and like a slave, outside humanity (Vernant, 1987: 22). This reference stands in parallel with what Agamben says about the rights of Man, when he underlies the point that these rights are, in fact, preserved within the limits of citizenship, and he adds that despite the centrality of the notion of citizenship in modern political thought, it remains ambiguous since citizenship itself as a determination is a sort of product of the regulatory provisions. On the other hand, for Marx, the citizen is a simple means for the conservation of these socalled rights of Man rather than directly being a criterion for the determination of "Man". So, in contrast with the references to the ancient Greek society and to Agamben, Marx considers the citizen as a servant of the egoistic man which is posed as the real and authentic man, namely as the bourgeois. Consequently, here we are not dealing with Man as a concrete, singular subject, as an individual having a human life, but Man as the bourgeois which is dressed in morality and religion via the purely abstract citizenship.

In this perspective, we can say that these key-notions like equality, liberty, property are quite abstract and they conceal the interests of the bourgeois class while being idealized under a universal form. Moreover, the notion of right itself is unjustifiable, since in a society determined by different classes, the variety of names which this notion receives in fact have no real counterparts. Considering the notion of liberty, for example, in the context of this declaration and in the following declarations, we realize through Marx's insistences on this point, that it is basically the question of the liberty of property. In On Jewish Question the property right is mentioned as "the right to enjoy and dispose of one's resources as one wills, without regard for other men and independently of society: the right of self-interest” (Marx, 2002: 59). This is the individual liberty which, with its application, forms the basis of the bourgeois society. It makes each person to see in another, not the realization but rather the limitation of his or her liberty. Above all, it proclaims the right to enjoy and dispose one's possession, income, product of his or her work and his or her labour-power as he or she pleases. So the problem here is, in fact, how to raise this notion of liberty to a more meaningful level? It may be possible for us to answer that question if we take into account Marx's dealing with the individual. In the Critique of the Gotha Programme, he puts forward the complete development, in other words, the blossoming of the individual, which would lead to the increase in the productive forces and to the cooperative richness of all the sources; in turn we would be liberated from the narrow horizon of the bourgeois right imposing on us a system of slavery. For Marx, the expression of our being an individual is the fact that we realize our species being; and this realization passes through the development of our personal faculties. The fact that the waged labourer is allowed to work in order to assure his existence as long as he works without being paid for a certain time (Marx \& Engels, 1972: 39) stands as the greatest obstacle in the way of self-knowledge. Because it alienates the individual from what he can do, while it also isolates him from others. The competitive, egoistic man that is particularly promoted by the declaration is, like a monad, closed in itself and has no connection with others, if it 
is not for satisfying his own needs. If we ask how this man finds himself in the tragic picture given by Marx we can refer to the following passage:

"The less you eat, drink, buy books, go to the theatre, go dancing, go drinking, think, love, theorize, sing, paint, fence, etc., the more you save and the greater will become the treasure which neither moths, nor maggots can consume- your capital. The less you are, the less you give expression to your life the more you have, the greater is your alienated life and the more you store up your estranged life (...) everything you are unable to do, your money can do for you.” (Marx, 1975: 361)

Marx underlies the fact that in this context, the individuality doesn't determine what one is, what one can do; but in its place, the inanimate, dead thing, namely the money does it. So under the rule of the dead, how can one get back his own living being? Surely not with the help of such a declaration of the rights of man and the citizen! Who are these man and citizen having such rights as liberty and equality from their birth? As a result of all the above-mentioned considerations, we say that these two are in fact one; the one as the bourgeois; the bourgeois with his rights. The most problematic point here is why one should ever need to draw limits among individuals by designating from the start the owner of such assignable "rights", which in fact are not rights at all - and especially if we consider the right in both ontological and political senses as what Hannah Arendt calls in The Origins of Totalitarianism as "the right to belong to humanity”. Maybe the rights in themselves should have been thought only as a free exercise of cultivating our personalities along with a freedom of choice whose sole condition would be that of the respected injunction that everyone can do so (Eagleton, 1997: 53). However as Marx considers Man as carrying also the title of citizen for the sake of his own interests, the citizenship also suggests the limits of nation, nationality (Agamben, 1998: 76). Parenthetically, we can state that for Marx, the form of the class struggle is itself national (Marx \& Engels, 1972: 36) and thus it becomes clear why such a declaration of rights must concern a capitalist society which, determined by the class struggle, poses itself as the actual society in all the civilized countries. So taking into consideration this national frame, we are allowed to reflect on the rights of Man (the bourgeois) as long as they are the rights of the citizen -which takes us again to the reference to the Ancient Greeks. As a result, we begin to realize the fact that there are always to be others beyond this limit/border imposed by the modern State-Nation (so the recent problem of refugees, as Agamben also points out, becomes much more complicated if they are to be deprived of these so-called inalienable rights). In such a context, how can we also interpret the right of equality?

In the Critique of the Gotha Programme, Marx puts an emphasis on the fact that this equal right is an unequal right for an unequal labour which takes into consideration no class distinction, because every man is nothing but a worker like all others. However the individuals are not equal and in the face of an equal measure they are considered only from one aspect (as workers, for instance) having their all other aspects (whether they are married or not, whether they have children or not etc.) abstracted in this way. Thus Marx underlies the fact that the right itself should be unequal, not equal. And it is only in a communist society where all the social inequality based on the subordination of individuals to the division of labour is eliminated and hence the differences of classes are suppressed that all the social and political inequality would disappear. It is only in 
such a society that individuals would be considered as living beings, along with their intellectual capacities, their talents...etc., the possibility of free development of their faculties always being open to them. Then labour would become not only a means of living, but also the first and foremost need of life. So the society would write to its banners: from each according to his ability, to each according to his needs! (ibid: 32) As a result, we would leave Man-Citizen behind the narrow horizon of an inferior phase, that is, of the capitalist society.

In conclusion, as Marx reveals the problematic character of Man and Citizen, he designates the core of the question relevant to them, as lying in the society itself, in its own structure. Thus we realize how at this stage where the class struggle is essentially determined by the division of labour, through this Man and this Citizen, a certain portion of society is favoured, while the individuals of the other portion have been forced to be alienated from their own forces, their own lives. However in a higher phase of the society these discriminatory and restrictive rights along with this Man-Citizen cooperation would be no longer needed. Eventually the egoistic man promoted by the market conditions and alienated from life itself would be replaced by human beings always in relation with others in a common world, and that would be what Marx calls human emancipation. 


\section{Marksçı Bir Perspektiften 1789 İnsan Hakları Bildirisinde İnsan-Vatandaş İşbirliği Sorunu}

\section{Özet}

1789 tarihli İnsan ve Yurttaş hakları Bildirisi insanlık tarihinde her zaman özgürlük, eşitlik ve mülkiyet hakkı alanlarında bir kazanım olarak görülmüştür. Bu bildirinin içerisinde anahtar kelimeler olarak "İnsan" ve "Yurttaş"1 bulurken genellikle bunların neyi temsil ettiklerinin farkında olmayız. Esasında "İnsan" ve "Yurttaş" ayrımının insanlara iki farklı alanda iki ayrı yaşam sürmelerini öneren bir kapitalizm olumlamasından başka bir şey olmadığının farkına varabiliriz. $\mathrm{Bu}$ da bize sanki hak talebini haklı çıkarmak için ortaya konmuş ahlak aşılanmış "yurttaş" gibi bir hukuki terimle birlikte gerçekte olduğu burjuvayı gizleyen soyut "İnsan”la karşılaşma imkânını verir. Bu noktada da kendi yöntemiyle söz konusu üstü örtüklüğe son veren Marx’1 buluruz. Dolayısıyla bu çalışma Marx’ın görüşleri ekseninde bildirideki "İnsan" ve "Yurttaş"ın kimliklerinin deşifre edilmesini amaçlamaktadır.

Öncelikle Hobbes ve Locke'nin bir yandan bencillik ve rekabet, diğer yandan eşitlik ve özgürlük mefhumlarıyla ortaya koydukları insan tanımlarından hareketle Marx'ın doğa durumundaki insanın sivil topluma mensup biriyle benzerliklerine dikkat çektiği eleştirisiyle karşılaşırız. Yahudi Sorunu Üzerine adlı metninde sivil toplum mensubu insanın vatandaştan ayrı, gerçek insan, hissi, dolayımsız varoluşundaki insan olarak alındığını, politik insanın ise, tersine, soyut ve yapay insan olduğunu söyler. Kısacası klasik toplumsal sözleşme teorileri kapitalist toplumu meydana getiren doğa durumundaki insan görüntüsü altındaki bencil bireylerin atomize yığınını yansıtan birer ayna görevi görmektedirler.

1789 tarihli İnsan ve Vatandaş Hakları Bildirisi’nde ise önce İnsan ve Vatandaş ayrımının, iki ayrı alanda, iki ayrı yaşam sürmeyi önerdiğini fark ederiz: özel alanda, başka bir deyişle birbirleriyle rekabet halindeki bireylerin meydana getirdiği sivil toplumda insan olarak; ortak yasaların ve çıkarların karakterize ettiği kamusal alanda ise vatandaş olarak. Vatandaş doğal durumdaki çıkar çatışmalarının sebep olduğu uygunsuzlukları önlemek için toplumsal sözleşmeye katılan insandır aslında; bunun karşılığında "doğal" haklarının garanti altına alınmasını bekler. Önemli olan nokta ise kapitalist sistemin hem doğal insanı hem de sözleşmenin bağladığı insanı, başka bir deyişle vatandaşı kabul etmesidir; zira düzenli bir toplum adına yapılan hak teslimi, söz konusu hakların kapitalizm tarafindan bazı sınırlamalara tabi tutulması ve aynı anda da özel alanda bu doğal haklarının keyfini çıkarmasına müsaade etmesidir. Herkesin herkese karşı savaşı, insanın en temel hakkı, özel mülkiyet hakkına bağlı "doğal" takas etme eğilimiyle ilişkili olan rekabet olarak yeniden tanımlanır.

Öte yandan vatandaş tanımının ahlaki bir tarafı da vardır. Yasalara bağlı, belirli görevleri icra eden herkes için geçerlidir. Marx’a göre bu ahlaki pozisyon bizi doğrudan dinsel çıkarımlara sevk etmektedir. İnsan mefhumu ise daha sorunludur. Türsel varlıktan hareketle gerçek insanın peşindeki Marx için bu insan, gerçek insana yapılan bir soyutlamanın ürünüdür. Marx'ın kapitalist toplum tanımını takip edersek bu İnsan'ın kimliğine yaklaşmamız mümkün olabilir. Ne de olsa söz konusu bildiri kapitalist sistemin olumlanması sayılır. Kapitalist toplum üretim için emeğin satılıp satın alındığı bir toplumdur. Bu noktada toplum bir yanda proletarya, diğer yanda burjuvazi olmak üzere ikiye ayrılır. Biri kaynakların 
hâkimiyetini elinden tutan egemen sınıftır ve ekonomik yapıya hâkim olan sınıf bu şekilde yasal, politik ve toplumsal bilinç formlarını belirler. İnsan ve Vatandaş Hakları Bildirisi de bir bakıma bu egemen sınıfın, başka bir deyişle burjuvazinin ortak işlerini idare etme girişimidir.

Agamben'in Homo Sacer adlı çalışmasında dikkat çektiği gibi bildirideki insan, vatandaşlığın sınırları içerisinde belirir; bu da bize eski Yunan polisini anımsatır; zira orada insan zaten bir hak öznesidir ve doğrudan bir politik aktördür. İnsan olmanın sınırlarının çizildiği eşitlikçi sayılan bu toplumun dışında kalanlar ise insanlığın dişında sayılmaktadır. Bu noktada Agamben insan haklarının esasında vatandaşlığın sınırları dahilinde muhafaza edildiğinin altını çizer. Vatandaşlık mefhumu modern düşüncede ne kadar merkezi konumda olsa da esasında yeterince muğlâktır. Marx'a göre ise vatandaş sadece sözde İnsan'ın haklarını muhafaza etmenin aracidır.

Eşitlik, özgürlük, mülkiyet gibi anahtar mefhumlar oldukça soyuttur ve evrensel bir form altında idealize edilirlerken esasında burjuva sınıfının çıkarlarını gözetmektedirler. Mesela özgürlük mefhumuyla aslında mülkiyet özgürlüğü mesele haline gelir. Burjuva toplumunun temelini meydana getiren, bu bireysel özgürlüktür. Herkes birbirinde kendi özgürlüğünün gerçekleşmesini değil, sınırlanmasını görür. Herkesin sahip olduklarının keyfini dilediği gibi çıkarabileceği beyan edilir. O zaman soru özgürlük mefhumunun nasıl daha anlamlı bir seviyeye yükseltilebileceğidir. Gotha Programı'nın Eleştirisi'nde Marx bize bir kölelik sitemini dayatan burjuva hakkının dar ufkundan, yabancılaşmadan bizi kurtaracak olan bireyin gelişiminden, kendini bilmesinden, tanımasından bahseder. Birey olarak varlığımızın ifadesi türsel varlığımızı gerçekleştirmektir. Bildiri'nin özellikle desteklediği rekabetçi, egoist insan ise kendi ihtiyaçlarını karşılamak için olmadıkça başkalarıyla bağlantısı olmaksızın, bir monad gibi kendine kapalı kalır.

Gotha Program'nın Eleştirisi'nde Marx eşitlik hakkını da eleştirir. Esasında söz konusu olan eşit olmayan bir emek için eşit olmayan bir haktır. Hâlbuki bireyler eşit değildir; yalnızca bir yönleriyle düşünülemezler, soyutlanamazlar. Marx hakkın kendisinin eşit olmamasının gerektiğinin altını çizer. Öte yandan bireylerin iş bölümüne dayanan bütün toplumsal eşitsizliğin elimine edildiği ve böylece sınıf farklarının bertaraf edildiği komünist bir toplumda bütün toplumsal ve politik eşitsizliğin ortadan kaybolacağını belirtir. Sadece böyle bir toplumda bireyler entelektüel kapasiteleri, yetenekleri... vs. ile beraber canlı varlıklar olarak göz önüne alınacaklardır. Kendilerini özgürce geliştirme imkânı onlara daima açık olacaktır. Emek yaşamak için bir araç değil, yaşamın ilk ve en önemli ihtiyacı olacaktır.

İnsan ve Vatandaş işbirliği ve bu mefhumların bize ayrı ayrı sunduğu sorunların, bu çalışmada, bizi toplumun yapısıyla yüzleşmeye götürmesi amaçlanmaktadır. Söz konusu işbirliğinin temelde hangi haklara talip olduğu ve bu hakların ne anlama geldikleri ve neleri sakladıkları, Marx'ın konuyla ilgili ortaya koyduğu tespitlerle ve toplumun daha ileri safhasına ilişkin gelecek tasavvurlarıyla beraber ortaya konulacaktır.

\section{Anahtar Sözcükler}

Toplumsal sözleşme, Doğal insan, Özgürlük, Eşitlik, Mülkiyet, Burjuvazi, Kapitalizm. 


\section{REFERENCES}

AGAMBEN, Giorgio (1998) Homo Sacer: Sovereign People and Bare Life, Trans. by Daniel Heller-Roazen, California: Stanford Uni. Press.

AMERIKS, Karl ed. (2000) German Idealism, Cambridge: Cambridge Uni. Press.

ARENDT, Hannah (1998) The Human Condition, Chicago: Uni. Of Chicago Press. Company.

ARENDT, Hannah (1962) The Origins of Totalitarianism, Ohio: The World Publishing

COFFIN, G. Judith, et al. (2002) Western Civilizations, New York: Norton.

CARVER, Terrel ed. (1991) The Cambridge Companion to Marx, New York: Cambridge Uni. Press.

MARX (1977) Capital, Vol: I. Trans. By Ben Fowkes. New York: Random House.

MARX \& ENGELS (1972) Critique des programmes de Gotha et d'Erfurt. Paris: Editions Socials.

MARX, Karl (1975) Early Writings, Harmondsworth: Penguin.

MARX \& ENGELS (1992) The Communist Manifesto, New York: Bantam Classic.

MARX \& ENGELS (2005) “The German Ideology”. Sociological Theory in the Classical Era: Text and Readings By Edles, Laura and Applerouth, Scott. USA: Sage Publications.

MARX, Karl (2002) “On the Jewish Questions”, Marx On Religion, ed. Raines, John C., Philadelphia: Temple Uni. Press.

Seuil.

VERNANT, Jean-Pierre (1987) “L’individu dans la cite”. Sur l'individu. Paris: Éditions 